\title{
REGIONALIZATION OF OVIDUCTS IN Boophilus microplus (CANESTRINI, 1887) \\ (ACARI: IXODIDAE) AND ITS POTENTIAL SIGNIFICANCE FOR FERTILIZATION
}

\author{
GARCÍA-FERNÁNDEZ, C., ${ }^{1,2}$ GARCIA, S. M. L., ${ }^{2}$ SCHNEIDER, F. L., ${ }^{2}$ SEVERINO, \\ A. G. ${ }^{2}$ and WINKELMANN, E. C. ${ }^{2}$ \\ ${ }^{1}$ Museu de Ciências e Tecnologia, Pontifícia Universidade Católica do Rio Grande do Sul, \\ Avenida Ipiranga, 6681, CEP 90619-900, Porto Alegre, RS, Brazil \\ ${ }^{2}$ Instituto de Ciências Básicas da Saúde, Departamento de Ciências Morfológicas, Universidade Federal do \\ Rio Grande do Sul, Rua Sarmento Leite, 500, CEP 90050-170, Porto Alegre, RS, Brazil \\ Correspondence to: Casimiro García-Fernández, Estrada Luiz Bettiol, 301, Belém Velho, CEP 91787-110, \\ Porto Alegre, RS, Brazil \\ Received November 20, 1998 - Accepted January 7, 1999 - Distributed December 22, 1999
}

(With 21 figures)

\begin{abstract}
The structural analysis of oviducts in Boophilus microplus (Canestrini, 1887) in different stages of ingurgitation has indicated that they are constituted primarily of an internal cylinder and an external cylinder with different cell types being found between them. Copulated females in active ingurgitation process show typical variations along the internal cylinder, and three regions can be defined: anterior, ring-like and transitional. Based on such regionalization, hypotheses were raised about where and how fertilization takes place, a process yet to be clarified for the acari.
\end{abstract}

Key words: acari, ticks, female reproductive system, fertilization.

\section{RESUMO}

\section{Regionalizações dos ovidutos em Boophilus microplus (Canestrini, 1887) (Acari:Ixodidae) e seu possível significado na fecundação.}

Uma análise estrutural dos ovidutos de Boophilus microplus (Canestrini, 1887) em diferentes fases de ingurgitamento permitiu detectar que eles estão constituídos basicamente por dois cilindros celulares, um interno e outro externo; entre os quais foram encontrados diferentes tipos celulares. Fêmeas copuladas e em processo ativo de ingurgitamento mostram variações típicas ao longo do cilindro interno podendo ser definidas três regiões: anterior, anelar e de transição. Com base em tal regionalização, hipóteses sobre onde e como ocorre a fecundação, processo ainda não elucidado até o momento para ácaros, são levantadas.

Palavras-chave: ácaros, carrapatos, aparelho reprodutor feminino, fertilização.

\section{INTRODUCTION}

Although fertilization in ticks is still unknown, most researchers believe that only the spermatozoon nucleus penetrates the ovum during the fertilization process. The main controversies are related to the site in the female genital tract where this happens and to how the male nuclear material penetrates the female cell (Oliver, 1982).

With respect to the fertilization site, in argasidea it is supposed to be in the oviducts ampoule, where mature spermatozoa or spermiophores accumulate; the oocytes would be fertilized as they pass through this region (Goroschenko, 1965, apud 
Balashov, 1972). In ixodidae, as in the case of Hyalomma asiaticum, because there is no specialization of the ampoule, spermiophores would accumulate in the anterior third of oviducts, where they would fertilize the oocytes as they pass there after ovulation (Balashov, 1972). Fertilization may take place in different places in argasidea and ixodidae (Oliver, 1982). Other authors suggest that fertilization might occur in the ovary, as Lees \& Beament (1948), Khalil (1969), Till (1961), Londt \& Spicett (1976), Kakuda et al. (1995) have concluded in studying Ornithodorus moubata, Argas arboreus, Rhipicephalus appendiculatus, Boophilus decoloratus and Haemaphysalis longicornis, respectively.

As to how fertilization takes place, it could be through phagocytosis of spermatozoa by oviduct cells, resulting in the release of male DNA molecules that would spread through the ovum shell, as reported by Geigy \& Wagner, 1957; Wagner-Jevseenko, 1958 and Geigy, 1962, in Ornithodorus moubata. Sokolov (1956) suggests that in ixodidae, the spermatozoa attack the oviduct's wall cells in order to nourish themselves from their liquefied cytoplasm and remain attached to them but leaving the end containing the nucleus free so as to be able to penetrate the ova that are passing through the oviduct's lumen.

Goroschenko (1965 apud Balashov, 1972) claims that, in argasidea, as the ovum passes through the ampoule, it would have its outer membrane (corion) dissolved by the spermatozoon, and only the spermatozoon's small nucleus would enter the female cell. The remaining tubular part of the male cell would not take part in fertilization and would be dissolved by secretions from the glandular epithelium of the walls of oviducts and uterus.

In studying Argas arboreus, Khalil (1969) suggests that the spermatozoon touches the epithelium of the distal oviduct by means of its apical organelle, piercing the wall and remaining coiled up inside of it. A few spermatozoa would degenerate inside these epithelial cells that would be simultaneously destroyed, there remaining only few flat, undifferentiated cells adjacent to the basal membrane. These cells' disintegrated nuclei would mix with the spermatozoa in the oviduct lumen. The lumen of the proximal oviduct would be occluded. Some spermatozoa would become rolled up and others would reach the ovary. In the ovary they could be observed in the pedicilar lumen penetrating the primary oocytes. The author also noted that, in living preparations, spermatozoa seemed to penetrate actively the oviducts' cells rather than being phagocytosed by them.

Brinton \& Oliver (1971) suggested that the opening present in the cuticular envelope of oocytes at the spot where they are attached to the funicular cells of Dermacentor andersoni could be a micropyla. Although such an opening is not wide enough as to permit the passage of spermatozoon into the oocyte inside, it may work as the place where the tailess spermatozoon attaches itself, permitting the extrusion of the nucleus into the ooplasm.

Finally, Oliver's words (1982) seem to summarize what we can say up to the present about fertilization in acari: "fertilization in acari is a mystery" and, according to Sonesshine (1991) merits further studies. Facing the uncertainty of when and how fertilization takes place in these parasites, specifically in Boophilus microplus, the authors try to perform a structural analysis of the oviduct and formulate some hypotheses in order to contribute to the clarification of such an intricate and relevant issue.

\section{MATERIAL AND METHODS}

The reproductive system of ingurgitated or partially ingurgitated female B. microplus specimens collected directly from naturally infested cattle in a farm in the city of Viamão, RS, Brazil, was dissected out in Shen liquid at $\pm 4^{\circ} \mathrm{C}$ and promptly transferred to $3 \%$ gluteraldehyde in $0.1 \mathrm{M}$ phosphate buffer $\mathrm{pH}$ 7.4. After fixation the oviducts were isolated from the rest of the reproductive system and were thereafter included in Epon. The material was cut into $1 \mu \mathrm{m}$ sections at RMC 6,000 and stained with toluidine blue. Other material was dissected out as previously described and fixed in $4 \%$ buffered paraformaldehyde and included in glycolmethacrylate. From the blocks, sections 2 to $3 \mu \mathrm{m}$ wide were obtained with glass blades or dry diamond. These sections were placed on slides over a water drop. Shortly these slides were placed on a hot board at $60^{\circ} \mathrm{C}$. As they dried up they were stained with hematoxylin-eosin. Without passing through the ascending alcoholic series, they were immersed in xylol and mounted on Canada Balsam or Entelan. 
Sections for electronic microscopy were obtained from oviducts fixed in $3 \%$ gluteraldehyde buffered in $0.1 \mathrm{M} \mathrm{PO}_{4}, \mathrm{pH} 7.3$ and post-fixed in $1 \%$ $\mathrm{O}_{\mathrm{s}} \mathrm{O}_{4}$ at the same buffer, cut at RMC 6,000 at a thickness of 50 to $60 \mathrm{~nm}$, contrasted in uranyl acetate and lead citrate and observed in a transmission electronic microscope JEOL JEM 1200.

The material used in the present work is stored in the Museum of Science and Technology at the Pontificia Universidade Católica do Rio Grande do Sul, Brazil

\section{RESULTS}

The two oviducts that form part of the female reproductive system of B. microplus are formed by two concentric cylinders. The more external one is constituted by round or short cubic cells and the more internal one by one or several cell layers, depending on the region considered and the ingurgitation state of females. Between these two cylinders different cell types are observed.

\section{Structure of oviducts in non-ingurgitated, young females}

Females that have just left the metanymph stage, not ingurgitated but copulated, with spermatozoa still restricted to the seminal receptacle, that is, without having reached the uterus, present oviducts with the same general pattern throughout its course. The internal cylinder is made up of high cells with a clear cytoplasm whose apex almost meet together determining the formation of a tiny lumen or even a virtual one. The rounded nuclei present chromatin-rich granules. Cell division figures are often seen. Fusiform cells with a dense cytoplasm and nearly compact nuclei are also observed. The external cylinder, quite thinner, shows smaller cells that are rounded or short cubic. Between the two walls differently shaped cells are visualized. (Figs. 1 and 2).

\section{Structure of oviducts in copulated, ingurgitating females}

In analyzing the structure of oviducts of copulated females, we have to take into account that spermatozoa move down the oviduct as a block, forming a compact mass that, as it moves, strains the oviduct's wall and dilate it. Following dilation there comes constriction (Fig. 3).
These females' oviducts are divided in the following regions: anterior region, ring-like region, and terminal, or transitional, region, which prolongs as far as the ovary. (Figs. 3, 4 and 5).

The spermatozoa mass can be found in several regions of the main part of oviducts, from the point where they converge (uterus) to the ringlike region. From this region on, however, no spermatozoa are observed. At the end of ingurgitation the ring-like region disappears, and by oviposition time spermatozoa can be found even in the ovary.

\section{Anterior region}

The cells of the internal wall in this region are tall, with clear nuclei and chromatin in the form of granules (Fig. 6). The lumen, at first tiny or virtual in non-ingurgitated young females, widens by the presence of the sperm mass that push the cells to the outside making them less tall. At the place where the spermatozoon make contact with internal wall cells, these show formations of apical processes (Fig. 7), which proved to be microvilli under the electronic microscope (Figs. 8 and 9). From then on, the internal wall cells will show a series of modifications according to the moment and extent of contact with the spermatozoon:

- The internal wall voluminous, clear nuclei, with chromatin in granules, are not observed anymore; extremely compact, irregular nuclei are increasingly observed (Fig 10).

- The apical cellular processes seem to be fused with the spermatozoa (Fig. 9). Thus, the cells of the oviduct's internal wall assume a vacuolated or lacy aspect (Fig. 10). Nuclei present different degrees of basophilia (Fig. 11).

- The small vacuoles fuse forming a great vacuole that enlarges gradually (Figs. 12 and 13).

- Within these large vacuoles a dense nucleus that becomes clearer and clearer is noted (Fig. 13).

\section{Ring-like region}

It is the continuation of the anterior region of oviducts as long as it contains spermatozoa masses.

The internal wall in this region is unique because it is divided in clearly defined compartments. The number of compartments is variable and ranges from 6 to 9 or over (Fig. 14). 

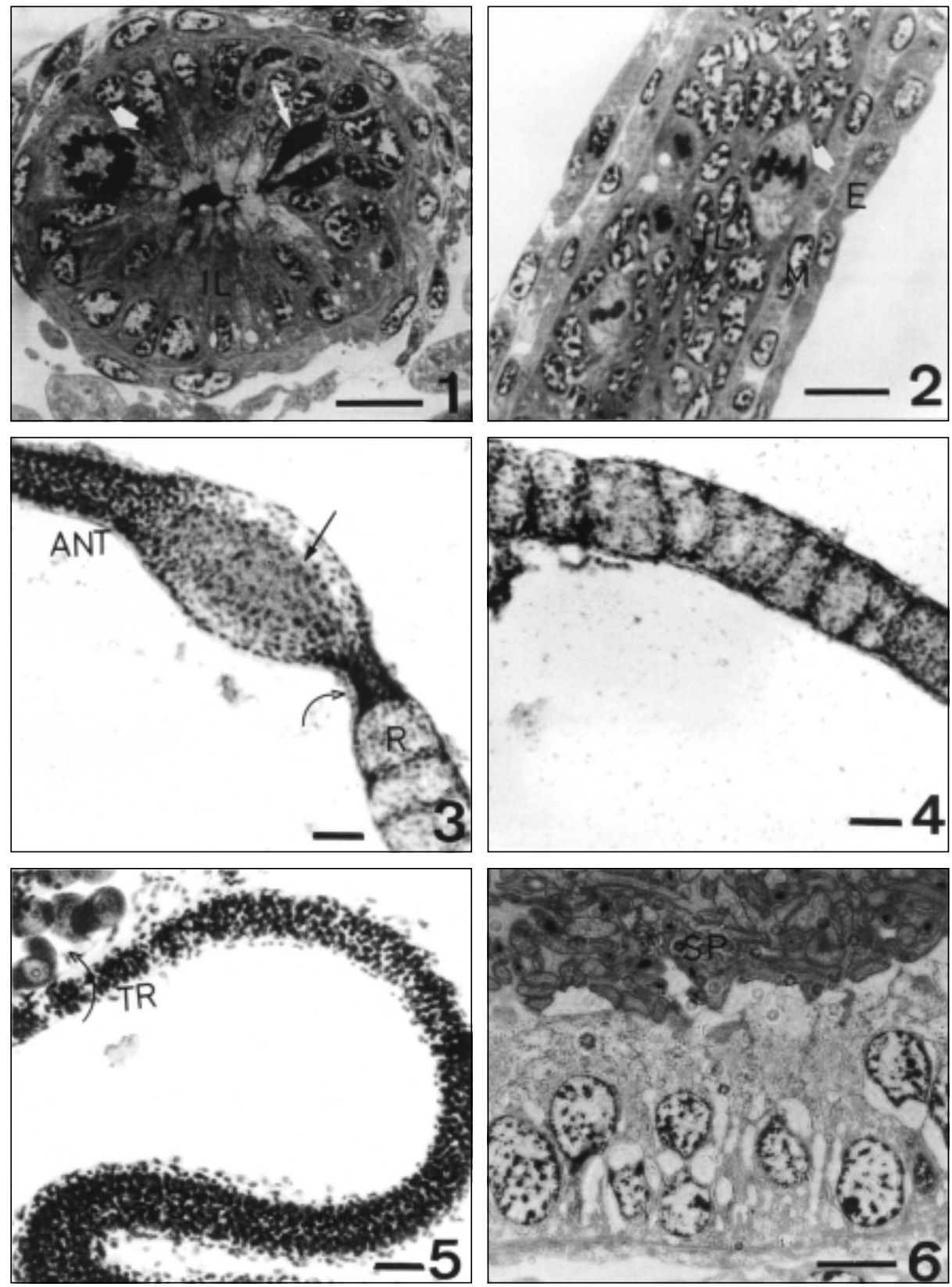

Fig. 1 - Transversal section of oviduct in female just departed from the metanymph stage, copulated and with spermatozoa still restricted to the seminal receptacle. Note in the internal cylinder cells in division (wide arrow) and fusiform cells (narrow arrow). Semi-thin section in Epon. Bar measures $10 \mu \mathrm{m}$. Fig. 2 - Longitudinal section of oviduct in female just departed from the metanymph stage, copulated and with spermatozoa still restricted to the seminal receptacle. Note three characteristic layers in the oviduct: internal (IL), external (E), middle (M). In the internal layer cells in division are observed (white arrow). Semi-thin section in Epon. Bar measures $10 \mu \mathrm{m}$. Fig. 3 - In toto preparation of oviduct in ingurgitating, copulated female. Anterior region (ANT), ring-like region (R). Note the spermatozoa moving as a block (narrow arrow) and constriction zone (curved arrow). Bar measures $100 \mu \mathrm{m}$. Fig. $4-$ In toto preparation of oviduct in ingurgitating, copulated female. Ring-like region. Bar measures $100 \mu \mathrm{m}$. Fig. 5 - In toto preparation of oviduct in ingurgitating, copulated female. Transitional region (TR), ovary (curved arrow). Bar measures $100 \mu \mathrm{m}$. Fig. 6 - Transversal section of anterior and initial region of oviduct. Note the close contact of spermatozooa (SP) with the internal wall of oviduct. Note the rounded, clear nuclei. Semi-thin section in Epon. Bar measures $10 \mu \mathrm{m}$. 

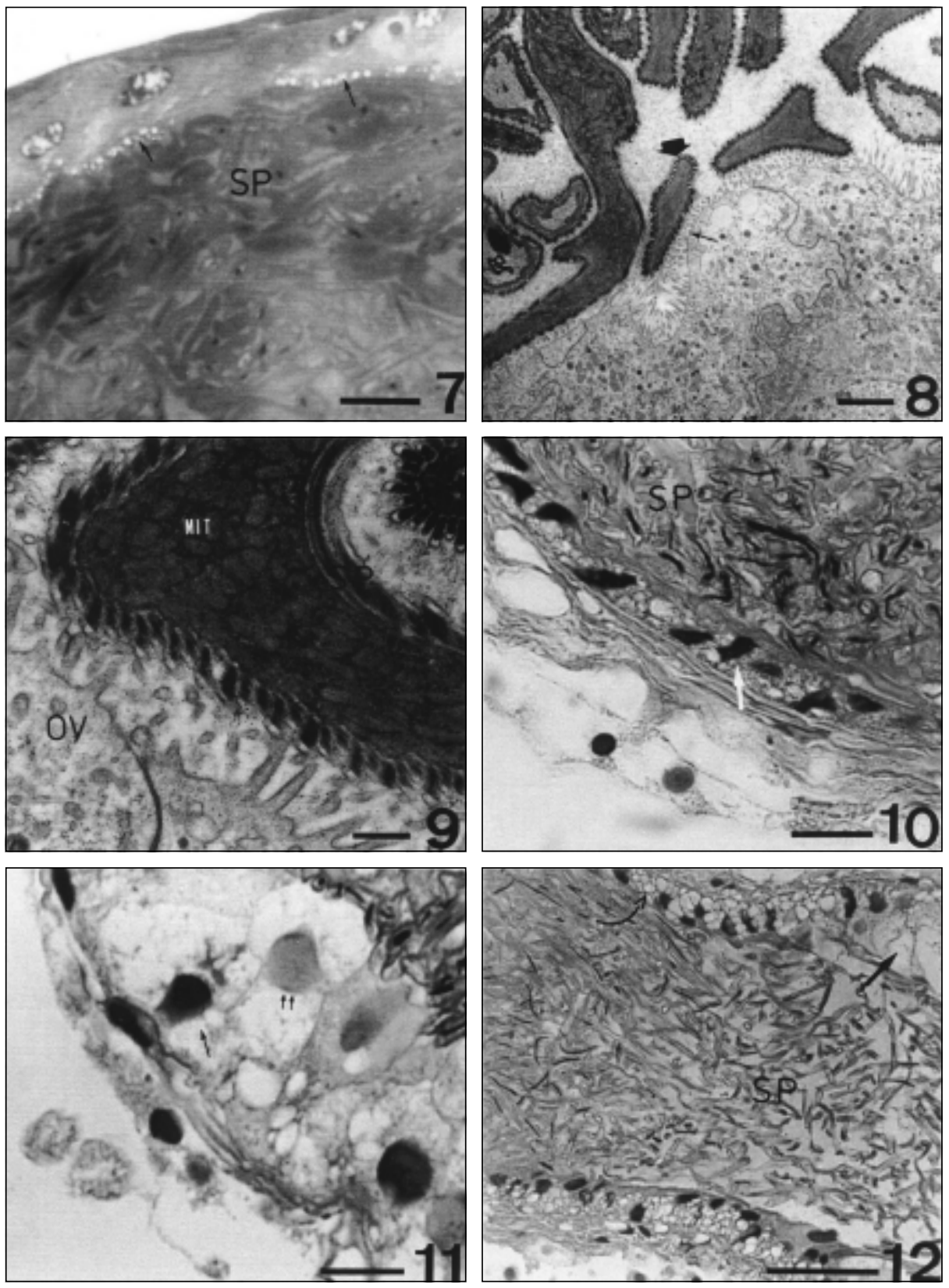

Fig. 7 - Transversal section of anterior region of oviduct showing the contact of spermatozoa (SP) and vesicles (arrows) of internal wall. Glycolmethacrylate HE. Bar measures $10 \mu \mathrm{m}$. Fig. 8 - Ultra-structure of transversal section of anterior region of oviduct. Note microvilli (narrow arrow) in the apical cellular portion and spermatozoa (arrow heads) attached to cell wall. Bar measures $2 \mu \mathrm{m}$. Fig. 9 - Ultra-structural detail in the apical celular portion of the anterior region of oviduct. Note the interrelation between microvilli of cells in oviduct (OV) and the folds in the spermatozoon (SP) wall. Note the abundance of mitochondria (MIT) inside the spermatozoon. Bar measures 0,5 $\mu \mathrm{m}$. Fig. 10 - Transversal section of anterior region of oviduct showing compaction of nuclei of internal wall cells (arrow). Note the enlargement of vesicles. Spermatozoa (SP). Glycolmethacrylate, HE. Bar measures $10 \mu \mathrm{m}$. Fig. 11 - Transversal section of anterior region of oviduct showing nuclei with different degrees of basophilia within large vacuoles. High basophilia (single arrow), low basophilia (double arrow). Glycolmethacrylate, HE. Bar measures $10 \mu \mathrm{m}$. Fig. 12 — Longitudinal section of anterior region of oviduct showing the transition in vacuole size. Numerous little vacuoles (curved arrow), large vacuoles (arrow). Glycolmethacrylate, HE. Bar measures $50 \mu \mathrm{m}$. 
The internal cylinder wall is formed by tall cubic cells showing large nuclei with the chromatin in granules. They rest on a basal layer. Their basal surface shows numerous membrane folds, while in their apical surface structures like microvilli are observed (Figs. 15 and 16). Compartmentalization of this region is achieved by projections of the very cells of the internal wall (Fig. 16). The cells of the external cylinder are round or almost flat and appear lined up (Fig. 15).

Between the external and internal cylinders there appear variously shaped cells, the most remarkable of which are cells with highly dense, round granules (Fig. 15).

The ring-like region arises during ingurgitation and lasts until the fully ingurgitated female detaches itself from the host. The spermatozoa never move beyond the ring-like region; instead they accumulate at the entrance to it. As full ingurgitation approaches, the number of rings decreases and the spermatozoa get closer and closer to the ovary. At the time when the tick falls from the host, the spermatozoa reach the ovary and the oviduct is progressively reduced to the external cylinder only, and no traces of spermatozoa are observed.

\section{Terminal, or transitional, region}

Afterwards, the internal cylinder cells become tall and their apices almost meet so as to practically obliterate the lumen of the oviduct (Fig. 17).

The tall, narrow cells show large, clear ovalshaped nuclei, with chromatin in granules, that appear at different levels. The cell region where the nucleus is located appears larger. In some cells the basal portion is narrower and the apical one wider; other cells show the opposite, that is, the basal portion is wider than the apical one. This way cells mold to each other. The cells' basal portion presents intense membrane folds, a configuration that resembles the internal cylinder cells in the ring-like region. Between the internal and external cylinders there appear cells that seem to be muscle cells (Fig. 17). Closer to the ovary, the oviduct's lumen becomes visible again (Fig. 18). Soon after that, oocytes can be observed in addition to the tall cells.

The presence of funicular cells under the emerging oocytes becomes clearly defined in the successive sequence (Fig. 19). A unique feature of the anterior region of the oviducts in females at any stage, except for females in the oviposition stage of ingurgitation, is that they are quite pleated. The external cylinder always follows the folds of the internal one.

\section{Oviducts of females in oviposition}

When the female is at the end of ingurgitation and prepares itself for oviposition, the oviducts lose their regionalization. The ringlike region disappears.

At this stage the oviduct is very long, becoming 10 times or more as long as its length in an ingurgitating female, because, as the process goes on, the oviduct unfolds and stretches out gradually.

Females in oviposition do not present the two characteristic cylinders. The oviducts' wall, as a whole, is reduced to a structure that is similar to a simple scamous epithelium (Fig. 20). Still, underlying such an epithelium an amorphous structure is observed.

As the ovum slides internally it expands the cylinder and touches its shell against the oviduct's wall (Fig. 21).

\section{DISCUSSION}

If the "when" and "how" fertilization takes place in ixodidae has not been clarified so far, it might be because it does not follow the known classic patterns.

In our search for support that might contribute to the clarification of the fertilization issue in ticks, we have come across highly structured oviducts and distinctive features depending on the region and on the ingurgitation stage in which they are analyzed.

The regionalization of oviducts in $B$. microplus, described for the first time here, is certainly related to fertilization.

Some relevant issues should be emphasized and questioned:

1) The spermatozoa usually appear as dense masses within the oviduct and in close contact with the internal cylinder

The spermatozoa of acari do not have a flagellum to allow it to move swiftly. Their movement as a mass facilitates their contact with the oviduct's internal wall. The agglomeration mechanisms presses them against the wall through which they are moving. 

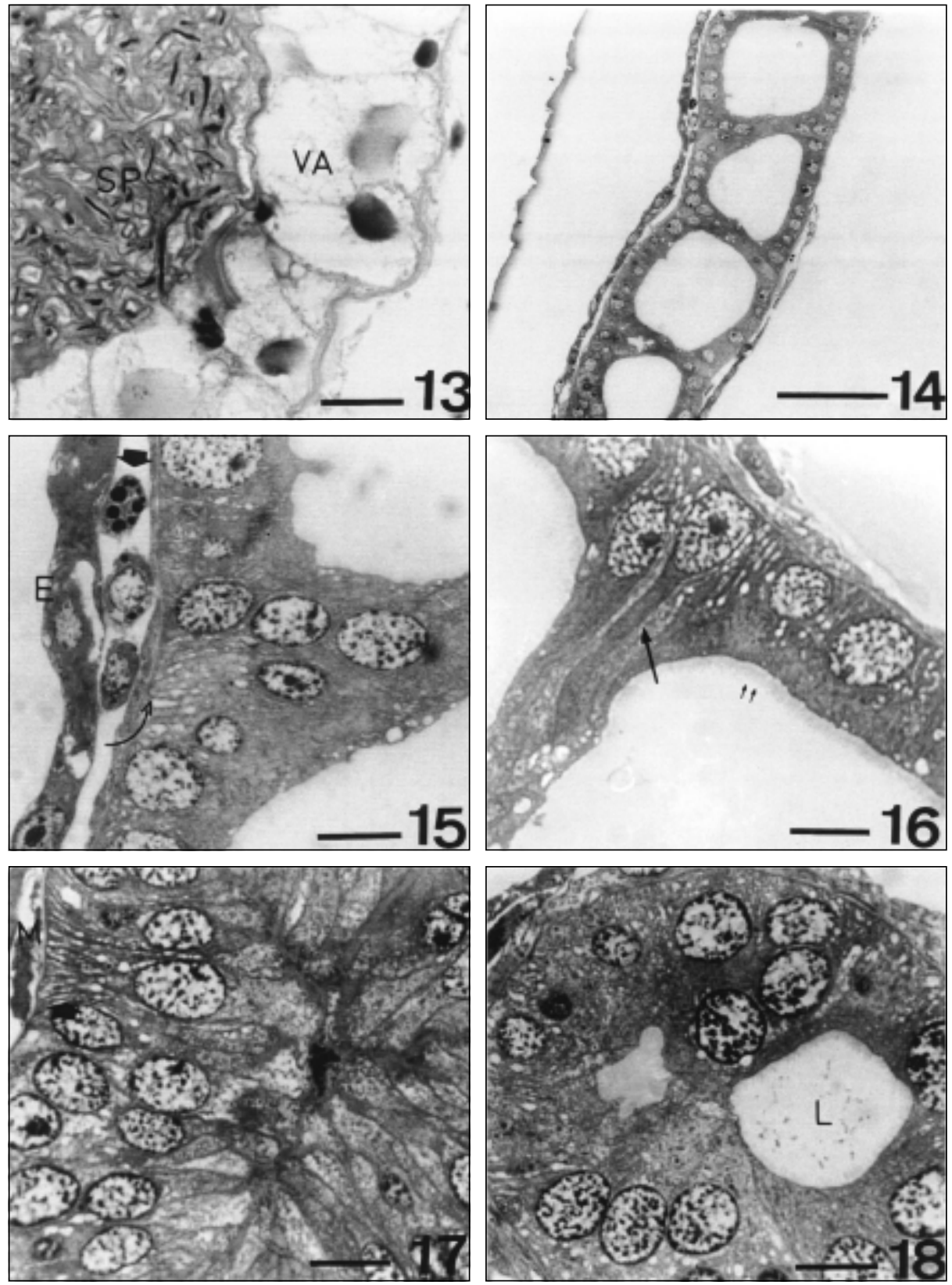

Fig. 13 - Transversal section of anterior region of oviduct showing large vacuoles (VA) with structures with different degrees of basophilia in the inside. Spermatozoa (SP). Glycolmethacrylate, HE. Bar measures $10 \mu \mathrm{m}$. Fig. $14-$ Longitudinal section of ring-like region of oviduct. Note the compartmentalization. Semi-thin section in Epon. Bar measures $50 \mu \mathrm{m}$. Fig. $15-$ Longitudinal section of a portion of the ring-like region. Note membrane folds on the cell basal surface (curved arrow). Note lined up cells in the external wall (E) and cells with dense granules between the two cylinders (arrow head). Semi-fine section in Epon. Bar measures $10 \mu \mathrm{m}$. Fig. 16 - Longitudinal section showing the partition between two chambers in the ring-like region. Note structures similar to microvilli (double arrows) in the apical cell surface and internal wall cell with a pronounced apical process that extends along the partition (long arrow). Semi-thin section in Epon. Bar measures $10 \mu \mathrm{m}$. Fig. 17 - Transversal section of transitional region of oviduct. Note the molding of the internal wall cells. Basal surface plenty with folds (arrow head). Virtual lumen, clear nuclei. Muscle cell (M). Semi-thin section in Epon. Bar measures $10 \mu \mathrm{m}$. Fig. 18 - Transversal section of the oviduct's region that is nearest the ovary in relation to the anterior one. Note the reappearance of the lumen (L). Semi-thin section in Epon. Bar measures $10 \mu \mathrm{m}$. 

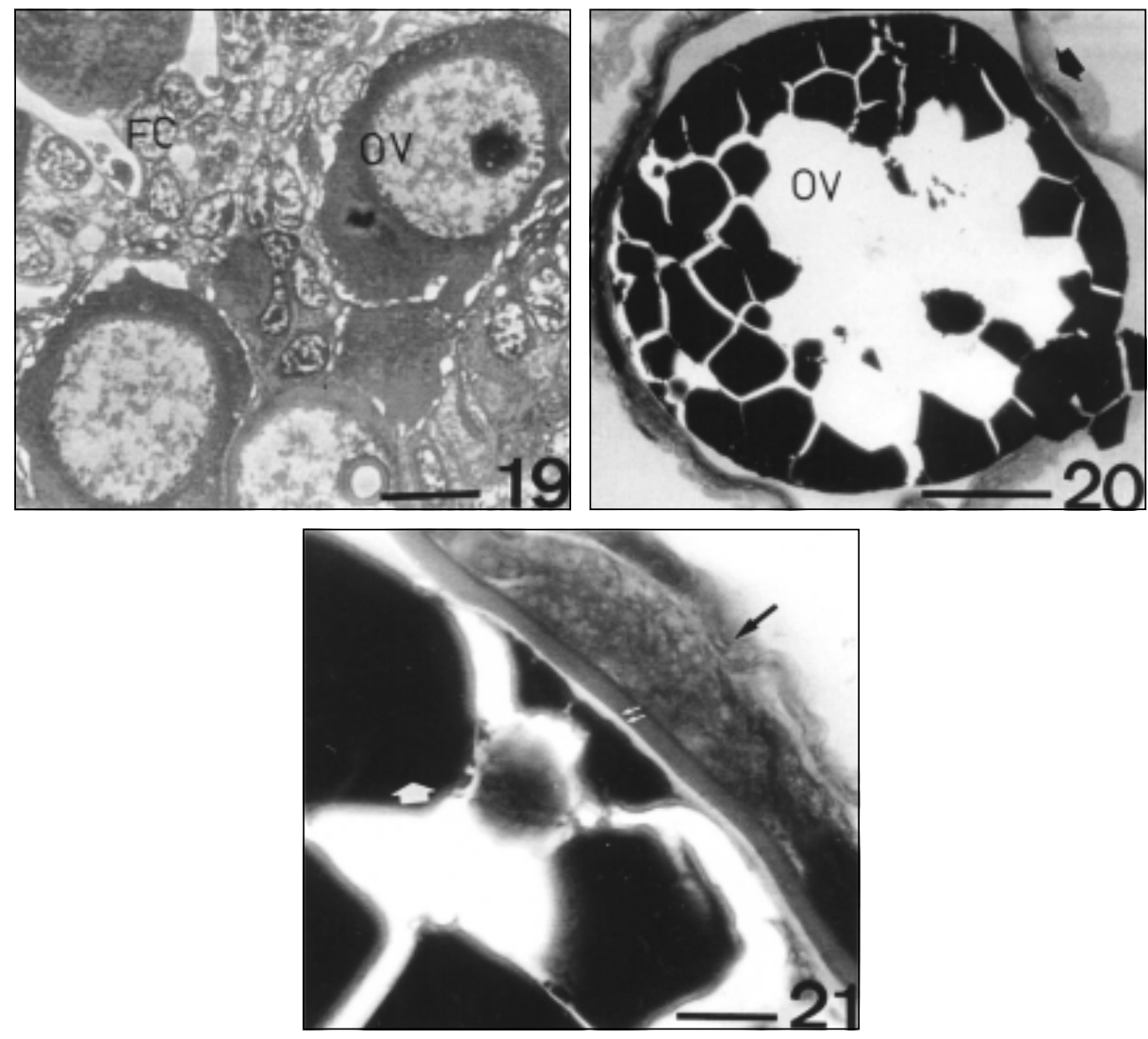

Fig. 19 - Transversal section of the end of the transitional region and the beginning of ovary. Note the presence of oocytes (OV). Funicular cells (FC). Semi-thin section in Epon. Bar measures $10 \mu \mathrm{m}$. Fig. 20 - Transversal section of oviduct from female in oviposition. Ovum in the inside (OV). The three layers are not observed anymore and the oviduct wall is limited to a thin layer (arrow head). Glycolmetacrylate, HE. Bar measures $50 \mu \mathrm{m}$. Fig. 21 - Detail of previous figure. Egg shell (double arrows), vitellus granules (arrow head), oviduct wall (arrow). Glycolmetacrylate, HE. Bar measures $10 \mu \mathrm{m}$.

The interrelation between spermatozoa and oviduct wall cells has been noted for a long time. In 1956 Sokolov observed that in ixodidae the spermatozoa remain stuck to the oviduct wall. Geigy \& Wagner (1957), Wagner-Jevseenko (1958), and Geigy (1962) reported the phagocytosis of spermatozoa by oviduct cells in Ornithodorus moubata and the release of male DNA molecules. Khalil (1969) noted that, in living preparations of Argas arboreus, the spermatozoa seemed to actively penetrate the oviduct cells. The present work has demonstrated that the attachment of the spermatozoon to the wall of the oviduct's internal cylinder is more than simply a contact or a phagocytosis. Apical cell processes of the oviduct's internal wall interact with the folds of the spermatozoon wall. Considering the number of mitochondria in the spermatozoon, such an interaction seems to be an active process on the part of the male gamete.

\section{2) Formation of vesicles in the cells of the internal} cylinder in contact with the spermatozoa culminating in the formation of a large vacuole

It seems to us that the gradual formation of little vesicles consists of an interaction of membranes of the internal cylinder's epithelial cells and membranes of the spermatozoon itself. Such an interaction is so remarkable that we suggest that this might be the moment and the place at which the male and female cells interact in the fertilization event. If this is so, this oviduct portion could actually be a portion of the ovary. The formation of small vesicles culminating in the appearance of a large vacuole 
could be related to polyspermy blockade. As a result of this there is a separation between the oviduct's wall and the remaining spermatozoa mass.

\section{3) Nuclear compaction and different degrees of nuclear basophilia}

The modification of the nuclei of the oviduct's internal cylinder cells, from rounded and granular chromatin to irregularly shaped, compact and with different degrees of basophilia, could indicate that syngamy might be occurring there.

If fertilization does occur in the suggested patterns, questions might be raised about the significance of the external cylinder. It seems likely that the fertilized cells now migrate through the external cylinder to populate what is known as ovary and initiate vitellogenesis. The oviduct folds, observed in all stages of the female, except for the female in oviposition, represent more efficiency in the contact of spermatozoa with the cells of the internal wall. The internal cylinder would actually be made up of female gamete cells and the external cylinder would be the oviduct proper, through which cells already fertilized would slide and eventually lodge in the ovary and, at a second moment when the oviducts are stretched out, take the ova for oviposition. If this is so, we think that what we call the oviduct is actually an ovarian region, which we could call germinarium and what is called ovary would in fact be the vittelarium of the ovary.

\section{4) Significance of the ring-like region}

The significance of the ring-like region, more precisely the importance of trabeculae in the fertilization process, seems to be related to a structural mechanism that prevents the spermatozoa mass from spreading along the oviduct, eliminating the effect of its movement as a group. At oviposition time, such cell processes that define the compartmentalization and are retractable and not observed anymore; these allowing free passage of the ova through the oviducts.

The idea suggested here is also supported by the exhaustion of oviducts at the moment of oviposition, demonstrating that at this time of the female's life they have already lost their significance, having become frail ducts that export eggs.
Acknowledgments - The authors are indebted to Daniel Bueno due to his support in translating this paper from Portuguese to English.

\section{REFERENCES}

BALASHOV, Y. S., 1972, A translation of bloodsucking ticks (Ixodidae) vetor of man and animals. Misc. Publs. Ent. Soc. Am., 8: 161-376.

BRINTON, L. P. \& OLIVER, J. H. Jr., 1971, Fine structure of oogonial and oocyte development in Dermacentor andersoni Stiles (Acari:Ixodidae). J. Parasitol., 57: 720747.

GEIGY, R., 62, Maturation des produits sexuels et phénomènes de fertilisation chez Ornithodorus moubata. Symp. Genet. Biol. Ital., 9: 77.

GEIGY, R. \& WAGNER, O., 1957, Ovogenese und Chromosomenverhältnisse bei Ornithodorus moubata. Acta Trop., 14: 88-91.

KAKUDA, H., NISNHIMURA, H., MORI, T. \& SHIRAISHI, S., 1995, Structural changes of the female genital system during and after feeding in Haemophysalis longicornis (Acari:Ixodidae). Jour. Fac. Agric. Kyushu Univ., 40 (1-2): 61-71.

KHALIL, G. M., 1969, Biochemical and physiological studies of certain ticks (Ixodidae). Gonad development and gametogenesis in Argas (Persicargas) arboreus Kaiser, Hoogstral and Khols (Argasidae). J. Parasitol., 55: 1278-1297.

LEES, A. D. \& BEAMENT, J. W., 1948, An egg-waxing organ in ticks. Quart. J. Micr. Sci., 89: 291-332.

LONDT, G. H. \& SPICETT, A. M., 1976, Gonad development and gametogenesis in Boophilus decoloratus (Koch, 1844) (Acarina:Metastriata:Ixodidae). Onderst. J. Vet. Res., 43: $79-96$

OLIVER, J. H. Jr., 1982, Tick Reproduction: Sperm Development and Cytogenetics. In: $F$. Obenchain \& $\mathrm{R}$. Galun (eds.), Physiology of Ticks. Pergmon Press, New York, Oxford, pp. 245-273.

SOKOLOV, I. I., 1956, The problem of fertilization in ixodid ticks. Zool. Zh., 35: 511-528.

SONENSHINE, D. E., 1991, Biology of Ticks. v. 1., Oxford Univ. Press. New York.

TILL, W. M., 1961, A contribution to the anatomy and histology of the brown ear tick Rhipicephalus appendiculatus Neumann. Mem. Ent. Soc. Sth. Africa, 6: $124 \mathrm{p}$.

WAGNER-JEVSSENKO, O., 1958, Fortpflanzung bei Ornithodorus moubata und genitale Übertragung von Borrelia duttoni. Acta Trop., 15: 118-168. 